ただし

$$
\delta_{1}=\frac{\left(k_{\mathrm{t} 11}\right)^{1 / 2}}{k_{11}}, \quad \delta_{2}=\frac{\left(k_{\mathrm{t} 22}\right)^{1 / 2}}{k_{22}}, \quad \phi=\frac{k_{\mathrm{t} 12}}{2\left(k_{\mathrm{t} 11} \cdot k_{\mathrm{t} 22}\right)^{1 / 2}}
$$

なお上式で $\phi, \delta_{2} / \delta_{1}$ の值を種々仮定して求めた重合速度と単 量体組成の理論曲線と実験結果を示すと図 3，4 のようになる。 この結果, 交互停止速度定数 (Cross termination constant) $\phi$ $=2.0, \delta_{2} / \delta_{1}=0.55$ の時, 実験値と理論値のよい一致がみられ た。ここで St の単独重合についての值 $k_{11}=176 \mathrm{l} / \mathrm{mol} \cdot \mathrm{sec}, k_{\mathrm{t} 11}$ $\left.=72 \times 10^{6} \mathrm{l} / \mathrm{mol} \cdot \mathrm{sec}^{20}\right)$ を用いると， $\delta_{1}=48.2$ となり，したかっっ て $\delta_{2}=26.5$ といら值が得られた。すなわち, AL と St の共重 合においては同種ラジカル間の反応より異種ラジカル間の反応の 方がわずかに優先的に起こるが，ほとんどの停止は同種ラジカル のカップリングによっていることがわかった。そこで AL と St の重合の共重合性のよいのは生長反応に起因しているものと思わ れる。また $\delta_{1}>\delta_{2}$ より，AL の重合体の方が St のそれよりも 重合度が大であることが推察される。

\section{4. 重合温度と重合速度の関係}

$\mathrm{AL}, \mathrm{St}$ の単独重合および AL と St の仕込みモル比が 1.00 の共重合における見掛けの活性化ェネルギーを求めると，それぞ れ $19.6,18.4$ および $16.9 \mathrm{kcal} / \mathrm{mol}$ なる值が得られた。

20) M. S. Matheson, E. E. Auer, E. B. Beivlaqua, E. J. Hart, J. Am. Chem. Soc., 73, 1700 (1951).

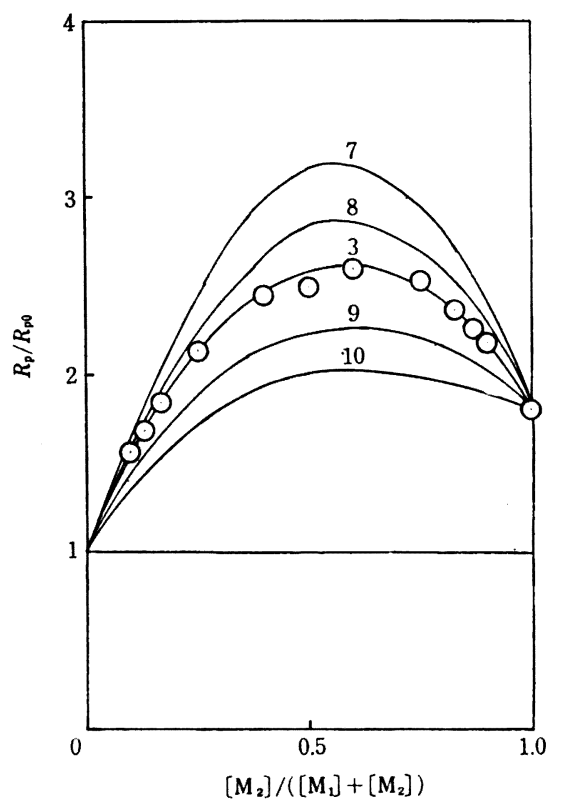

困 4 単量体組成と共重合速度の関係（ $\phi$ の变化） $0:$ 実測值

$\delta_{2} / \delta_{1}=0.557: \phi=1.0,8: \phi=1.5,3: \phi=2.0,9: \phi=3.0,10: \phi=4.0$

\title{
塩化ビフェニルテトラソニウムと塩化銅（Ｉ）の付加化合物からポリフェニレンの合成*1
}

(昭 和 43 年 12 月 9 日受 理)

\author{
羽山茂・新野昭 伍 ${ }^{* 2}$
}

塩化ビフェニルテトラソニゥム（BTC と略記）と塩化銅（I）の付加化合物は非常に活性で，有機溶媒の $10 \sim 20 \mathrm{vol} \%$ 水溶 夜中 $80^{\circ} \mathrm{C}$ で重合した。重合体のベンゼン溶液から分別して得られたポリフェニレンの分子量は $10,000 〜 16,000$ であった。分別 体はペンビン, テトラヒドロフラン，1４-ジオキサン，クロロホルムに溶けた。BTCの 20 wt \% 水溶液に塩化銅（I）を 2 倍も ル反応させてつくった付加化合物からは分子量の高い成分が得られた。しかし BTC 水溶液に塩酸, アンモニア，塩化ナトリウム が存在すると，重合体の分子量は著しく低下した。重合の活性化ェネルギーは $10 \mathrm{kcal} / \mathrm{mol}$ であった。

分別体はわすかに結晶性で融点を示さなかった。元素分析, 赤外吸収スペクトルから, これらは $p$ ーポリフェニレンのアン化合 物であると判断された。それらの電気伝導度は $20^{\circ} \mathrm{C} て ゙ ~ 10^{-8} \sim 10^{-10} \Omega^{-1} \cdot \mathrm{cm}^{-1}$ であった。

\section{1 腥言}

芳香族化合物からのポリフェニレンの合成は，その耐熱性およ び電気伝導性を期待して，種々の研究が行なわれた ${ }^{1 \sim b)}$ 。しかし 生成物はほとんど有機溶媒に溶けず，高分子量体を分離できなか った。それらのらち, Berlin の発表したベンジジンのテトラジ 化液にアンモニア性 $\mathrm{Cu}^{+}$を作用させる方法, ${ }^{8)}$ は染料化学の応用

*1この報交を「可溶性ボリフェニレンの合成（第1 報)」とす る.

*2 Shigeru HAYAMA, Shôgo NIINO 山形大学工学部高分 子化学科：米沢市城南 4 丁目.

1) A. Edward, G. Goldfinger, J. Polymer Sci., 16, 589 (1955)

2) C. Marvel, G. Hartzell, J. Am. Chem. Soc., 81, 448 (1959).
として興味を持たれたが6)，結果は同じであった。芳香族アミン のジアゾ化液にアンモニア性 $\mathrm{Cu}^{+}$を作用させると，ビフェニル 誘導体が得られるが，その際主生成物よりもアゾ化合物や副生成 物の方が多く生じるといわれている7。

著者らは極めて濃厚なベンジジンのテトラゾ化液から塩化ビフ エニルテトラゾニウムを結晶させ，それを水に溶ふして，塩化銅 （I）との付加化合物を作った。これは非常に活性で，有機溶媒

3) A. A. Berlin, J. Polmer Sci., 55, 62i (1961).

4) A. A. Berlin, V. I. Liogonkii, V.P. Porini, ibid., 55, 675 (1961).

5) P. Kovacic, A. Kyriakis, J. Am. Chem. Soc., 85, 454 (1963).

6）籏野昌弘，野口宏道，高分子，11，1004（1960）.

7）“化学実験学, 第 2 部, 合成編 III", 河出書房 (1942), p. 474 . 
水溶液中で加熱すると, 発泡しながら重合して, ポリフェニレン となった。本報告では，分子量の高いポリフェニレンを合成する ための付加化合物の生成条件，および重合体の特性について述べ る。

\section{2 実験}

$2 \cdot 1$ 塩化ビフェニルテトラソニウム（BTC と略記）の単離 極めて濃厚なべンジジンのテトラゾ化液から BTC を結晶でと り出した。BTC 単離法の記述は見当らないので, 簡単に説明す る。ベンジジン塩酸塩 $13 \mathrm{~g}(0.05 \mathrm{~mol})$, 水 $15 \mathrm{ml}, 35 \%$ 塩酸 $15 \mathrm{~m} l$ の混合溶液に亜硝酸ナトリウムの 飽和水溶液 $(15 \mathrm{~g}(0.2$ $\mathrm{mol}) / 30 \mathrm{ml})$ を $5 \sim 10^{\circ} \mathrm{C}$ で滴下し, テトラゾ化した $(15 \mathrm{ml}$ 必 要)。そのあと全量を加えて $0^{\circ} \mathrm{C}$ に一夜放置した。析出した黄色 の結晶をロ過し，冷アセトンで洗浄した（収率 70\%)。

\section{2 付加化合物の生成}

BTC $7 \mathrm{~g}(0.025 \mathrm{~mol})$ の $20 \mathrm{wt} \%$ 水溶液に塩化銅（I） $5 \mathrm{~g}$ $(0.05 \mathrm{~mol})$ を粉末か少量の水て懸濁させて加え, 液温を $10^{\circ} \mathrm{C}$ 以 下に保った。反応溶夜に BTC が認められなくなると（確認 1), 生じた茶色の沈殿を素焼板上で脱水した。

\section{$2 \cdot 3$ 重合と分別}

脱水した付加化合物はたたちに $N, N$-ジメチルホルムアミド (DMF) の $20 \mathrm{vol} \%$ 水溶液 $50 \mathrm{ml}$ に入れ， $80^{\circ} \mathrm{C}$ に 1 時間加熱 した。その間, 激しく発泡して, 沈殿は黒褐色に変わった。反応 中に塩素ガスは発生せず, 溶液中には次亜塩素酸イオンが検出さ れなかった（確認 2)。反応終了後塩化銅（I）は塩化銅（II）に 変わっていた(確認 3 )。ガスの発生が終ったあと, 酢酸を少量加 えて 30 分間煮沸し, 不純物を溶解した。沈殿は十分熱水洗浄後 乾燥した。

重合生成物（黒褐色）はメタノールで洗浄（ソックスレー抽出） し，そのあとベンゼンに溶かし，不溶解物を口別した。ベンゼン 溶液に石油ベンジンを少量加えて，分別沈殿を行なった。

\section{$2 \cdot 4$ 分子量測定および元素分析}

分別体は, 特級ベンゼンに溶かして, “Hitachi-Perkin·Elmer 115 型”分子量測定器を用いて，VPO 法で分子量を測定した。 元素分析は柳本製 “CHN Corder” を用いて, 炭素, 水素, 窒素 の同時定量を行なった。酸素と塩素は同社製 “OX Corder”を用 いて定量した。また赤外吸収スペクトルは日立回折格子型“EPIG 2”を使用して求めた。

\section{5 確認法}

$2 \cdot 5 \cdot 1$ ジアソ基 ${ }^{8)}$ 口紙上で $\beta$-ナフトールとのジアゾカップ リングによる呈色試験を行なった。

$2 \cdot 5 \cdot 2$ 塭素ガスと次亜塩素酸イオン9）ヨウ化カリウムデンプ ン紙を水で湿らせて, 塩素ガスにかさすと, 青紫色に変わる。口 液を微酸性にをて，1 $\mathrm{N}$ 酶酸鉛を滴下すると，白沈を生じ，加熱 すると褐色になる。

2.5.3 塩化銅（I）と塩化銅（II） 塩化銅（I）はアンモ二 ア水以外のアルカリ水溶液には溶けず, 黄褐色沈殿となる。塩化 銅（II）はアルカリ夜に入れると青色溶液となる。

8）日本化学会編，“実験化学講座（第 20 巻）有機化合物の合 成 II"，丸善 (1956)，p. 347

9）日本化学会編，“化学便筧基碟編 II”, 丸善(1966), p. 1320.

\section{3 結 果 と考 察}

\section{1 付加化合物の生成条件と重合体}

3・1・1 BTC の濃度 BTC $7 \mathrm{~g}$ を純水に溶かして濃度のちが った液を作り，これに $5 \mathrm{~g}$ の塩化銅（I）を作用させて作った 付加化合物を 2·3 の方法で重合させた。図 1 亿重合体の収率およ び分別体の分子量に対する BTC 濃度の影響を示す。BTC の濃 度が高いと，ベンゼン可溶成分は多くなるが，分別体の分子量 （分子量の最高値）は $20 \mathrm{wt} \%$ 程度が最も大きくなった。一方, ベンゼン不溶解成分は BTC の低濃度液の方が多くなった。

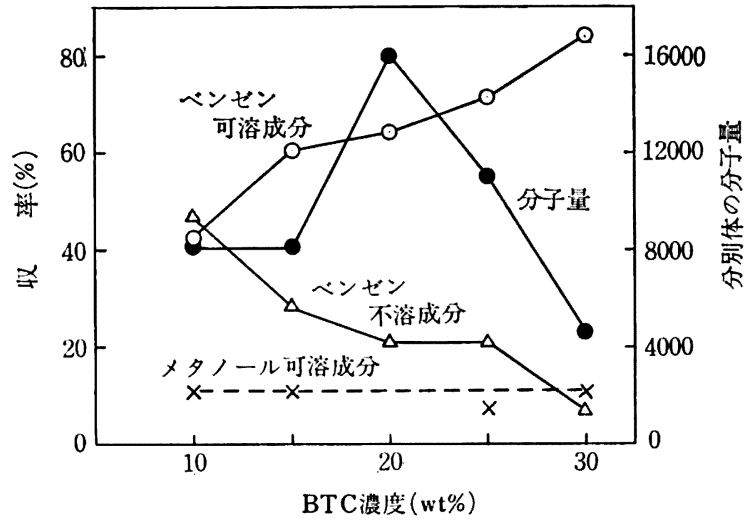

図 1 付加物形成時の $\mathrm{BTC}$ の濃度（CuCl を 2 倍モル添加）

3.1.2 BTC に対する塩化銅（I）のモル比 図 2 は BTC 20 $\mathrm{wt} \%$ 水溶液に塩化銅（I）のモル比を変えて作用させ, 2.3 の 方法で得られた重合体の収率を示す。モル比 1.5 以下ではべンゼ ン可溶成分の収率は低下したが，分別体の分子量は变わらないよ らである。それらでは付加化合物形成時に未反応の BTC が残っ ていた。BTC 水溶液は付加化合物を脱水するとき除かれるので, 重合体の収率は下るが，分子量には，差がなくなったと考えられ る。

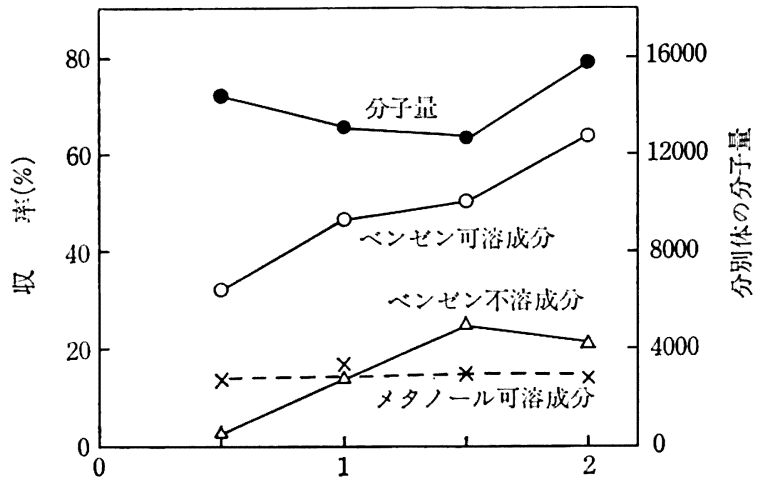

壏化銅(I)のモル比

図 2 BTC に対する塩化銅（I）のモル比

$3 \cdot 1 \cdot 3$ 重合媒体としての DMF 水溶液の湦度 因3に2.2 の 方法で作った付加化合物を DMF の濃度を変えた水溶液中で重合 させて, 分子量変化を求めた。DMF の濃度は 10 30 vol\% の とき，分子量の高い成分が得られた。濃度がこれ以上高いときは 重合初期から液が黒色となった。初期重合体が高濃度の DMF 水 溶液に溶解して，高分子量成分ができにくいと考えられる。

図 1〜3 の結果より，BTC 水溶夜と塩化銅（I）から作った 


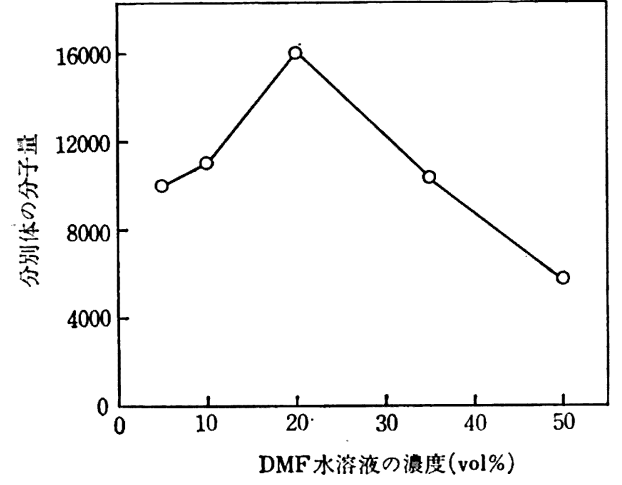

因 3 DMF 水溶液の濃度変化と分別体の分子量

付加化合物を DMF 水溶液中で加熱重合させるときの最適条件 は, BTC 濃度が $20 \mathrm{wt} \%$, 塩化銅（I）はBTCに対して 2 倍 モル, DMF 濃度は 20 vol\% となった $(2 \cdot 2,2 \cdot 3$ 参照)。以下 の実験はこの条件で行なった。

3.1 .4 共存イオンの影粱 BTC $7 \mathrm{~g}$ の $20 \mathrm{wt} \%$ 水溶液に塩 化ナトリウムを溶かしておき，付加化合物形成および重合に対す る塩化ナトリウムの影響を図 4 に示す。ベンゼン可溶成分の収率 は塩化ナトリウムの BTC に対するモル比が 3 まで大差ないが, 分別体の分子量は著しく低下した。塩素イオンおよびナトリウム イオンが共存すると BTC と銅（I）の配位が妨害され，そのよ らな付加化合物からは高分子量体ができにくいと考えられる。

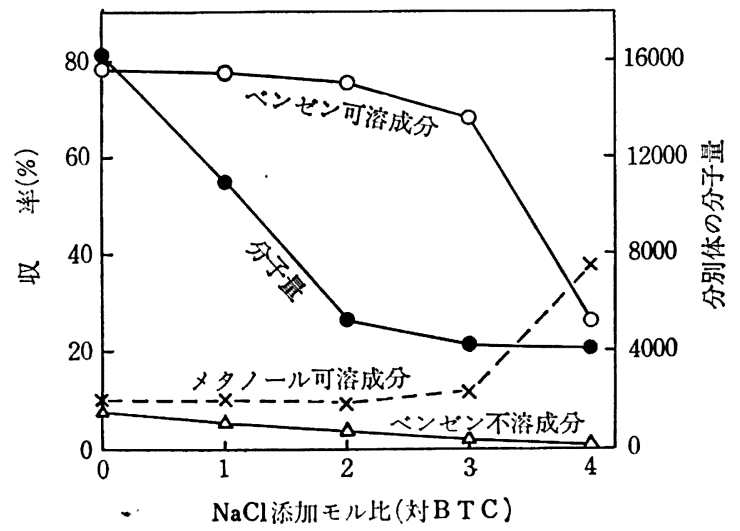

図 4 BTC $20 \mathrm{wt} \%$ 水溶液への塩化ナト リウム添加モル比と分子量

次に付加化合物形成時の酸およびアルカリの影響を調べた。困 5 は酸性, アルカリ性液中で付加化合物を作って重合させた時の 収率および分別体の分子量を示す。酸性側の付加化合物は BTC $5 \mathrm{~g}$ を塩酸水 $10 \mathrm{ml}$ に溶かしておき, 同じ規定度の塩酸水 $10 \mathrm{ml}$ に.3.6g の塩化銅（I）（モル比 2) を䯚濁させながら加えて作 った。BTC はアルカリ水溶液に入れると，ただちに反応して有 機溶媒に溶けないポリマーを作る。そこでアルカリ側の付加化合 物を作るには, BTC $5 \mathrm{~g}$ を純水 $10 \mathrm{ml}$ に溶かしておき，アンモ ニア水 $10 \mathrm{ml} に 3.6 \mathrm{~g}$ の塩化銅（I）を懸濁させながら加えた。 したがって図 5 のアンモニアの規定度は実際に使用した規定度の $1 / 2$ の值で示されている。

図 5 において塩酸およびアンモニアの $1 \mathrm{~N}$ 以下の夜を用いて 作った付加化合物から分子量の高い成分が得られ，濃厚な酸性お

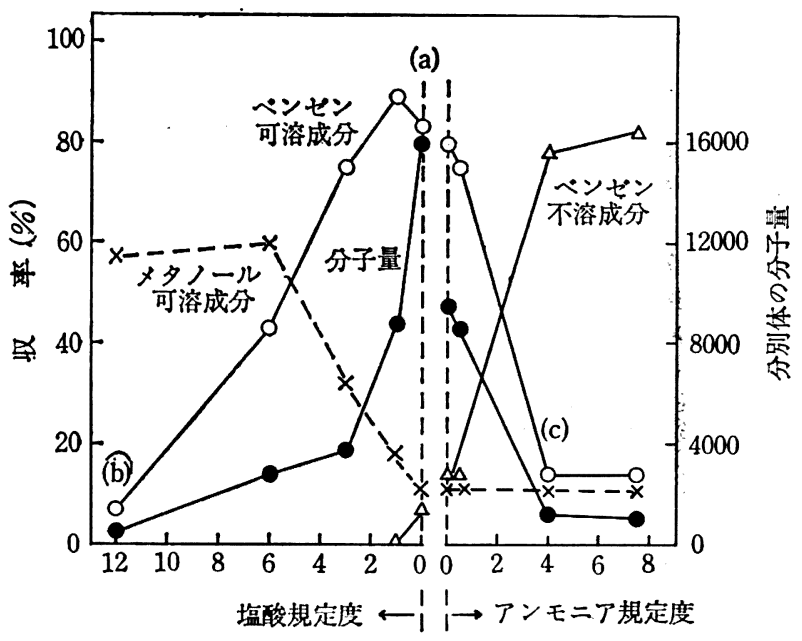

因 5 酸性, アルカリ性液中の付加化合物生成と重合体

よびアルカリ性液で作った付加化合物を重合させると，生成物は 著しく違ったものになった。酸性が濃くなると, メタノール可溶 成分が多く，ベンゼン溶解成分は直線的に減少し，分子量す極め て小さくなった。塩酸が付加化合物の配位を妨げたと考えられ る。一方, 濃厚アンモニア水の場合は, 大部分がベンゼン不溶解 成分で, 少量の可溶成分でも分子量は 1100 程度であった。この 場合は, BTC 水溶液にアルカリ液を加えたときの生成物と似て いた。付加化合物の形成よりも BTC に対する水酸イオンの作用 が優先すると考えられる。

\section{$3 \cdot 2$ 重合体の分別と組成およひ構造}

2・2，2·3で作った重合体を分別して，各区分ことの測定結果 を表 1 に示した。表 1 の区分 1 と 2 はベンゼン，テトラヒドロフ ラン (THF)，1，4-ジオキサン，クロロホルムには完全に溶けた が, DMF, メチルエチルケトン (MEK) には一部溶けないもの が残った。分子量の小さくなる区分ほど多くの有機溶媒（アセト ンなど）によく溶けた。一方，ベンゼン不溶解成分は THF にわ ずかに溶けて，その他の溶媒には溶けなかった。

\section{表 1 重合分別体の分子量と組成}

\begin{tabular}{|c|c|c|c|c|c|c|c|}
\hline 区分 & 色 & $\begin{array}{l}\text { 收事 } \\
(\%)\end{array}$ & 分子 量 & $\mathrm{mp}_{(\mathrm{C})}$ & $\begin{array}{l}\mathrm{N} \\
(\%)\end{array}$ & $\begin{array}{l}\text { 組 : フェ } \\
\text { 成 }=\text { 基数 }\end{array}$ & アゾ \\
\hline 1 & 黒裸色 & 7 & 16,000 & なし & 3.1 & 204 & 20 \\
\hline 2 & "I & 6 & 11,300 & "I & 3.0 & 144 & 14 \\
\hline 3 & 裸 色 & 6 & 5,000 & 310 & 2.9 & 64 & 6 \\
\hline 4 & " & 6 & 3,800 & 290 & 3.3 & 48 & 5 \\
\hline 5 & " & 28 & $<"$ & - & - & - & - \\
\hline 6 & 黄褐色 & 15 & メタノール可溶 & - & - & - & - \\
\hline 7 & 莱裸色 & 21 & ベンゼン不溶 & なし & 3.6 & - & - \\
\hline
\end{tabular}

図 5 の (a)：中性付近，（b）：酸性，（c）：アルカリ性に相当 する重合分別体の赤外吸収スペクトルを図 6 に示す。図 6 の (a) は 3030 3000 cm (フェニル核の $\nu-\mathrm{CH}$ ) のほか, $1600 \mathrm{~cm}^{-1}$, $1480 \mathrm{~cm}^{-1}$ ( ${ }_{x}=ル$ 核の $\nu-\mathrm{C}=\mathrm{C}$ ), $1100 \mathrm{~cm}^{-1}, 1000 \mathrm{~cm}^{-1}$ (フェ ニル核の面内 $\delta-\mathrm{CH}), 810 \mathrm{~cm}^{-1}(1,4$-置換 フェニル) に強い吸 収を示す。これらのうら $1480,1000,810 \mathrm{~cm}^{-1}$ 付近の吸収は,

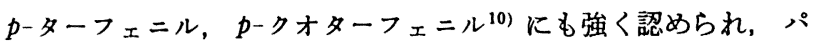
ラフェニレンに特有な吸収とされている2,5)。

$1600 \mathrm{~cm}^{-1}$ の吸収はベンゼン核に非共有電子対をもつ基がつい

10) J. E. Stewart, M. Hellman, J. Rẹ. Natl. Bur. Std., 60, 125 (1958), 


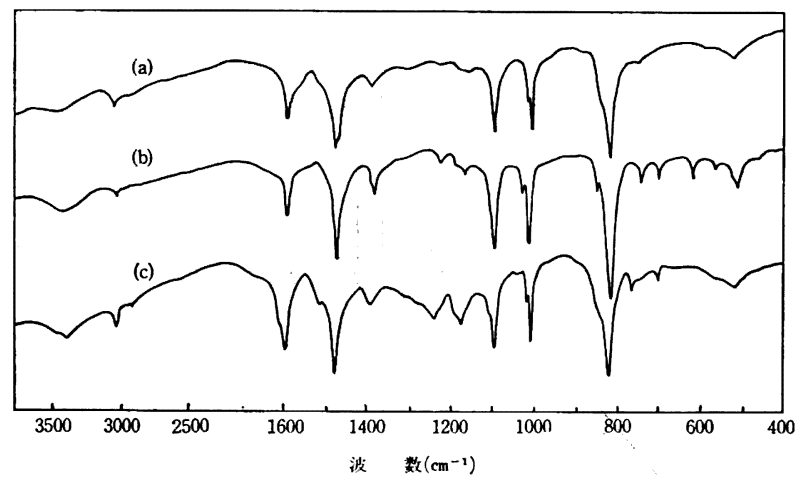

因 6 重合分別体の赤外吸収スペクトル 付加化合物形成条件 (a)：中性付近，(b)：酸性，(c)：アルカリ性

たとき強くなるといわれ(1)，この付近の吸収は $p$-ターフェニル， pークォーターフェニルには弱いが，アゾペンゼンには強く現われ る。また $1100 \mathrm{~cm}^{-1}$ の吸収はフェニル基に極性基がついたとき

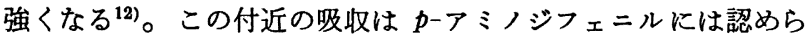
れないが, アゾベンゼンおよび $p$-アミノアゾベンゼンでは強く 現われる。したがって（a）の分別体は $p$-ポリフェニレンのア ゾ化合物と考えられる。

表 1 の分別体成分の元素分析值はいずれも炭素と水素の比が誤 差の範囲内で $72: 4$ の割合となり, 酸素と塩素は “OX corder” で直接定量したが，どちらも検出できなかった。そこで炭素と水 素をフェニル基, 窒素をアジ基と考えて, フェニル基数とアり゙基 数を計算して表 1 に掲げた。いずれもその割合は $10: 1$ 程度と なった。

図6の（b）は（a ）とほとんど同じである。p-クォターフェ ニルにも認められる ${ }^{10)}$ 末端フェニルの影響が $1400 \mathrm{~cm}^{-1}(\delta-\mathrm{CH})$ および $700 \mathrm{~cm}^{-1}$ (面外 $\delta-\mathrm{CH}$ ) 付近に現われた。この試料（分子 量 2670）から酸素は検出されず，塩素は $13.5 \%$ （末端基を塩素 と考えた値の 5 倍）存在した。強酸性で付加化合物を作ったた め, 赤外吸収スペクトルの $700 \mathrm{~cm}^{-1}$ の吸収は塩素 $(\mathrm{C}-\mathrm{Cl})$ の影 響とも考えられ，複雑な置換反応が起こったといえよう。

図 6 の (c) は (a) の吸収以外に, $3300 \mathrm{~cm}^{-1}$ 付近 $(\nu-\mathrm{OH})$,

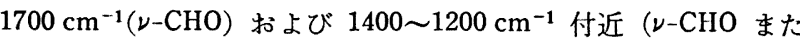
は $\nu-\mathrm{OH})$ の吸収が現われた。アルカリ性で作った付加化合物か ら DMF で重合したため, - $\mathrm{OH}$ と一-CHO が導入されたと考えら れる ${ }^{13)}$ 。この試料（分子量 1190）の酸素は $1.3 \%$ 検出された。 またこの試料に対応するベンゼン不溶解成分は酸素が $2.8 \%$ 検出 され，ベンゼン可溶成分の 2 倍になった。赤外吸収スペクトルも $1700 \sim 1200 \mathrm{~cm}^{-1}$ Kかけて幅広い複雑な吸収帯が見られた。この 重合条件では付加化合物形成より直接アンモニアと BTC の反応 が優先し， BTC のフェノール化，ついでジアゾカップリングな

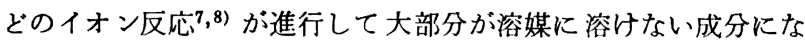
ったといえよう。

表 1 の 1，2 の区分は黒色に近く，ベンゼン不溶解成分は茶褐 色であった。色調からいえば深色的成分が共役二重結合が長いと

11）中西香爾, “赤外吸収スペクトル定性編”, 南江堂（1966）, p. 32 .

12）中西香爾, “赤外吸収スペクトル演習編”, 南江堂（1966）, p. 134 .

13) S. Yaroslavsky, Tetrahedrọn Letters, 1503 (1965).
考えられる ${ }^{14)}$ 。そこで分子量 10,000 近くの成分を 1,4 -ジオキ サンに溶かし, 清浄な銅板上に塗布して, 薄膜を形成させ, $20^{\circ} \mathrm{C}$

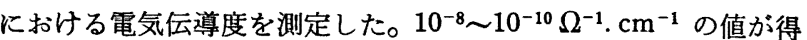
られた。

\section{$3 \cdot 3$ 付加化合物の反応性}

$3 \cdot 3 \cdot 1$ 重合媒体 $2 \cdot 2$ で作った付加化合物は, DMF 以外にジ メチルスルホキシド (DMSO), THF, MEK，アセトン, ピリジ ンおよびそれらの水溶液中でも重合した。得られた結果を表 2 に 示す。これらの重合媒体は水溶液濃度が 50 vol\% 以上になると， 初期重合体を溶かして，重合体の分子量が大きくならなかった $(2000 \sim 3000)$ 。

表 2 重合媒体を変えた重合体

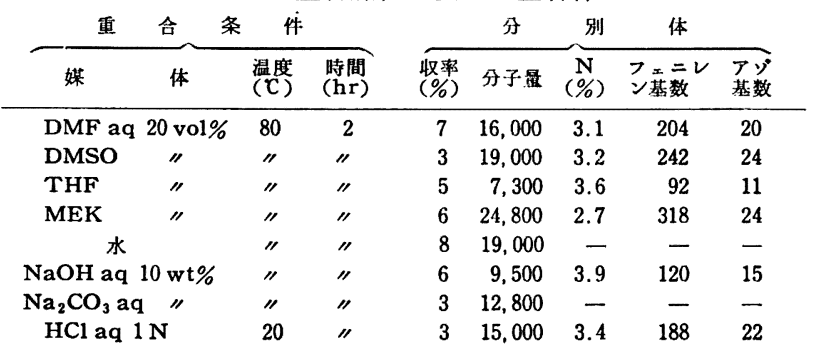

次に $2 \cdot 2$ の付加化合物は有機溶媒水溶液のほか, アルカリ水溶 液および塩酸水溶夜中で加熱しても重合した。結果を表 2 にまと めて示した。中性付近で作られた付加化合物は活性であるから， これらの液中でも重合が進み，高分子量のベンゼン可溶成分を生 成することが示される。

表 2 の分別体の赤外吸収スペクトルはいずれも図6の（a）と よく一致した。元素分析值は，窒素だけわずかに異なるが，炭 素, 水素の割合はほとんど変わらなかった。酸素, 塩素の検出は 困難であった。重合媒体は違っても分別体の組成および構造はほ とんど変わらない（アゾ基の割合は違う）と考えられる。また表 2 の分別体は真空中および空気中で加熱すると，いずれも $350^{\circ} \mathrm{C}$ 前後で軟化するが，そのあと硬化して，500ㄷ に加熱しても融解 しなかった。真空中で $500^{\circ} \mathrm{C}$ に加熱したものの赤外吸収スペクト ルは変化しないが，ベンゼンその他の溶媒に溶けなくなった。ま た空気中で $500^{\circ} \mathrm{C}$ に加熱したものは酸素は検出されなかったが, 重量が $5 \%$ 減少し，窒素もほぼ同程度の減少率であったっこれも 溶媒にはまったく溶けなくなった。炭素, 水素, 窒素の放出でラ ジカルが発生し, 複雑な橋かけ反応が起こったと考えられる。

表 2 の分別体のX 線回折写真は, いずれもわずかに結晶性を示 し，三つのリングが認められた。それらの写真から求めた面間隔 と自記 X線装置で記録したピークから求めた面間隔は，いずれの 場合も，ほぼ致した值になった。それらはすでに報告されてい $ろ^{2,5)}$ 結晶性ポリフェニレンの面間隔とよく一致し, $9.26 \AA ， 6.4$ Å, 3.4 4.5 (ゆるやかなピークで最も強い) であった。

3.3.2 重合機構 BTC と塩化銅（I）の付加化合物が DMF 水溶液中の加熱で重合する機構は式（1）で示される。式（1） の反応速度を窒素の発生速度を目安として求め, 四 7 から活性化 $\left[\mathrm{BTC}+\mathrm{Cu}_{2} \mathrm{Cl}_{2}\right] \mathrm{DMF}_{\mathrm{aq}}$ 付加化合物 $]$ 加

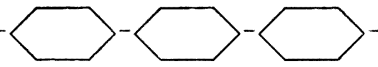
$+2 \mathrm{~N}_{2}+2 \mathrm{CuCl}_{2}+\mathrm{DMF}$

14）日本化学会編, “実験化学講座（第 1 巻）基礎技術 I (上)”, 丸善 (1959), p. 188 . 
エネルギーを計算して, $9.8 \mathrm{kcal} / \mathrm{mol}$ の值が得られた。この值は 加熱によるラジカル発生の活性化エネルギーより少ない(約 $1 / 2)$ 。 したがって式（1）はBTC と銅（I）の配位か DMF 水溶液に よりたち切られてラジカルを発生し, ラジカル同志の結合で重合 すると解釈される。DMF 以外の有機溶媒水溶液の作用も同様と 考えられる。

次に塩酸水溶夜, 純水, アルカリ水溶液中での加熱重合の活性 化エネルギーを実測して 10〜12 kcal/mol の值を得た。これらの 水溶夜も, DMF 水溶液と同様の作用で付加化合物を重合させる と考えられる。

(昭和 43 年 4 月, 日本化学会第 21 年会に一部発表)

終りに，赤外吸収スペクトル，X線回折の測定に御協力いただ いた本学石场教授, 松田助教授, 岡本講師ならびに電気伝導度を 測定していたたいた電子工学科犬飼助手に感謝する。また元素分 析，分子量測定を行なった遠藤技官に感謝する。

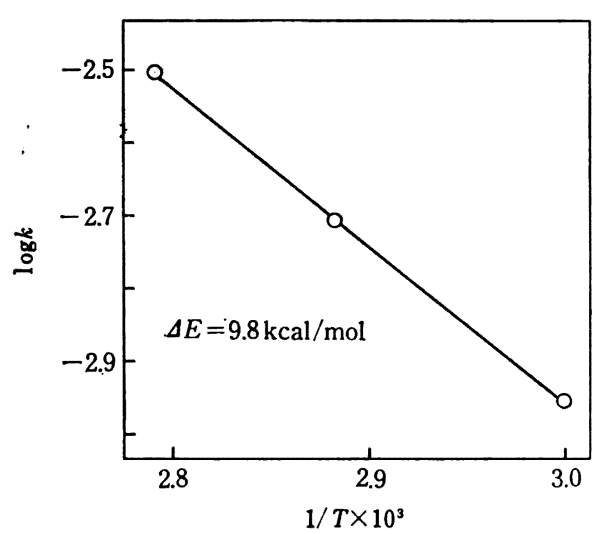

因 7 活性化エネルギー

\section{ポリ（エーテル）ウレタンエラストマーの過塩妻酸解重合}

(昭 和 44 年 1 月 27 日 受 理)

\section{鈴 木 肇・小 野 浩*1}

ポリオキシテトラィチレングリコールをェーテルセクメントとするポリ（エーテル）ウレタンェラストマーの過塩素酸解重合を $15^{\circ} \mathrm{C}$ より $60^{\circ} \mathrm{C}$ の間で検討した。その結果ポリェーテルセグメントの解重合は主鎖のエーテル基の酸素にプロトンが付加して分 解が始まりテトラハイドロフランになる。この活性化ェネルギーは䄪 $12 \mathrm{kcal} / \mathrm{mol}$ であった。

ウレタンセグメントの分解速度はポリエーテルセグメントの分解速度より小さく，またウレフセグメントはこの条件ではほとん ど分解せず，次の構造のポリウレアオリゴマーとして分離された。

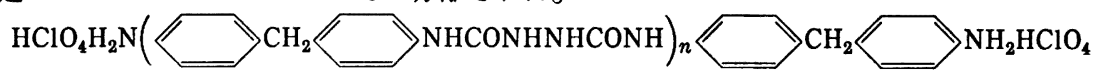

このポリウレフオリゴマーの数平均分子量は末端滴定法により求めた。分析結果とランダム重合反応と仮定して計算した值とを

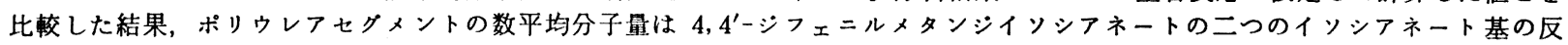
応性が等しいとして求めた值より大きい事が認められた。

\section{1 楮言}

重合体の解重合または劣化反応を利用して重合体の組成分布の 研究を行なった報告は多数1,2) ある。しかしポリ(エーテル)ウレ タンエラストマー (PEUE) の組成分布について研究された報告 はない。そこでポリオキシテトラメチレングリコール (PTG), ヒドラジン (HD) および 4, $4^{\prime}$-ジフェニルメタンジイソシアネー ト (MDI) より合成される PEUE の解重合により組成分布の検 討を試みた。PEUE の構造は複雑で次の三つのセグメントより なっているといえる。

$$
\begin{aligned}
& \text { ポリエーテルセグミント }\left(-\mathrm{OCH}_{2} \mathrm{CH}_{2} \mathrm{CH}_{2} \mathrm{CH}_{2}-\right)_{n} \\
& \text { ウレタンセグメント } \\
& (-\mathrm{OCONH} \longrightarrow \mathrm{NHCOO-}
\end{aligned}
$$

*1 Hajime SUZUKI, Hiroshi ONO 東洋紡䋩䋐維研究所: 大 津市本堅田町.

1) K. J. Bombaugh, C. E. Cook, B. H. Clampitt, Anal. Chem., 35, 1834 (1963).

2) A. Barlow, R.S. Lehrle, J.C. Robb, Polymer, 2, 27 (1961).

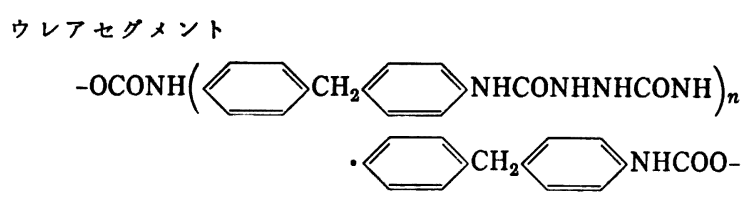

これら個々のセグメントの酸引) またはアルカリ4)による分解を 扱った報告はあり，PEUE のアルカリ解重合)についても検討さ れている。しかしこれらの反応では組成分析には利用されるが， 組成分布の解析には利用できない。そこで PEUE の過塩素酸解 重合反応に各セグメントのモデル重合体を用いて検討し, PEUE の組成分布の解析に利用することを試みた。

\section{2 実験}

$2 \cdot 1$ 試 料

PEUE は二段重合法により，MDI および HD と分子量 1000

3) T. Hoshino, T.Mukaiyama, H. Hoshino, J. Am. Chem. Soc., 74, 3097 (1952).

4) I. Christenson, Acta. Chemica Scandinavica, 18, 843 (1964).

5) R. J. Corrish, Anal. Chem., 31, 1298 (1959). 